\title{
IN MEMORIAN
}

\section{Geraldina Porto Witter 1934-2014}

As perdas são parte da vida. Há, no entanto, algumas que deixam um vazio difícil de ser preenchido. Este é o caso da Professora Geraldina Porto Witter - uma pessoa que, por atacar resolutamente as dificuldades, realizou sempre o que para outros constitui-se em uma simples aspiração. Ela deu exemplo pela própria maneira de viver. Educou e ensinou ao mesmo tempo e, por isso, foi um estímulo à formação de tantas pessoas que, como eu, tiveram o privilégio de sua convivência mais próxima. Com rigor e carinho bem dosados no processo de orientação, mostrava sempre a alegria de, pelo desenvolvimento de seus estudantes, reconhecer o dever cumprido. De aparência tímida, quando necessário tomava as rédeas nas mãos e saltava para superar as barreiras de um cotidiano tenso e controverso como se apresenta a universidade brasileira e, especialmente, a Psicologia.

Professora Geraldina pertenceu a uma geração de profissionais, os quais migraram da Educação para a Psicologia, tomando, no entanto, com muita responsabilidade e dedicação os dois campos de conhecimento e de profissão, ao mesmo tempo em que integrava temas, questões e produção de conhecimento que servissem à essa relação, até hoje, bastante discutida. Saída da Escola Normal de Mogi das Cruzes como professora alfabetizadora, cursou Pedagogia em nível superior especializando-se em Psicologia e, desde então, dedicou sua vida às questões do Ensino Público brasileiro. Escrevia com muita facilidade, certamente porque lia muito. Silenciosa na expressão oral, pois mais ouvia do que falava, sua escrita transbordava demonstrando que seu diálogo, mediado por suas reflexões e ideias escritas, tinha sempre o objetivo de ir além daqueles com quem conversava, presencialmente. Demonstrava carinho com pequenos e importantes gestos, por exemplo, todo Natal enviava uma caixa cheia de pequenas lembranças para cada um de nós. Meus quatro filhos a conheciam de um modo especial, mesmo considerando uma relação de orientador/orientando que durou 10 anos! Conversava como amiga em mo- mentos que precisávamos de uma palavra amiga. Mas era exigente quanto ao compromisso com a produção científica. Valorizava as atividades de orientação e sempre procurava organizar espaços coletivos de debates sobre as pesquisas individuais. Nesses momentos, tínhamos a oportunidade de conhecer um número enorme de mestrandos e doutorandos, de todas as partes do Brasil e da América Latina e, em uma época que a pós-graduação não se estruturava em Grupos de Pesquisa, ela já nos fazia sentir em um grupo. Sabíamos que essas relações seriam o alicerce de nossas atividades acadêmicas ao longo de nossas vidas. Ao nos orientar, ela nos ensinava a ser orientadores e orientadoras do futuro. Talvez por isso, o impacto de sua ação na formação de professores de Psicologia pelo Brasil todo foi enorme. Orientou mais de 254 pesquisas em cursos de Pós-Graduação (175 mestrandos e 79 doutorandos informados até 2004, na publicação de uma autobiografia - Educação e Psicologia: 50 anos de profissão, publicado por Ateliê Editorial em São Paulo e, gentilmente, amorosamente, doado a cada um de seus orientandos como uma lembrança infinita de sua presença em nossas vidas!).

Com suas palavras, finalizo esta breve homenagem: "Vou continuar a jornada até o ponto em que o caminho acabe ou me leve para outros horizontes. Vou continuar ciente de que não fiz tudo o que devia ou podia. Procurei fazer o que pude, nas várias circunstâncias. Vou em busca de ser melhor enquanto caminho. Que meu relato possa ser útil para que outros encontrem, façam e refaçam seus caminhos. Que o amor seja nosso denominador comum no trabalho e fora dele".

OBRIGADA por ter deixado marcas na vida de tantas pessoas e, principalmente, por ter ajudado a construir a PSICOLOGIA brasileira.

Raquel Souza Lobo Guzzo Estudos de Psicologia Editora Associada 
